\title{
A COMPARATIVE STUDY OF CELL BLOCK WITH CONVENTIONAL SMEAR CYTOLOGY IN DIAGNOSING SEROUS EFFUSIONS- A DESCRIPTIVE STUDY
}

\author{
Ravi Singh1, Sukhwant Singh Hayer2, Vaibhav Pandurang Mane ${ }^{3}$, Rupali Gopal Yelave ${ }^{4}$, Vishrabdha Rahul Pawar ${ }^{5}$ \\ ${ }_{1}^{1}$ Senior Resident, Department of Pathology, Bharati Vidyapeeth Deemed University Medical College and Hospital, Sangli. \\ ${ }^{2}$ Senior Resident, Department of Pathology, Bharati Vidyapeeth Deemed University Medical College and Hospital, Sangli. \\ ${ }_{3}^{3}$ Associate Professor, Department of Pathology, Bharati Vidyapeeth Deemed University Medical College and Hospital, Sangli. \\ 4Senior Resident, Department of Pathology, Bharati Vidyapeeth Deemed University Medical College and Hospital, Sangli. \\ 5Professor, Department of Pathology, Bharati Vidyapeeth Deemed University Medical College and Hospital, Sangli.
}

\begin{abstract}
\section{BACKGROUND}

Conventional cytology is the branch of pathology dealing in diagnosis of various fluids. But screening of remaining residue, which is not processed may be of paramount importance for diagnosis. The residual material may be evaluated by cell block preparation. Cell block study along with conventional smear cytology may improve the sensitivity of diagnosis. It is widely accepted that cellblock technique increases the cellular yield and improves diagnostic accuracy. The ability to obtain numerous tissue sections allows for multiple immunostains and other studies to be performed akin to paraffin sections produced in histopathology.

Aims and objectives- The present study is undertaken to assess diagnostic efficacy of cell block preparation (CB) by combined approach of conventional smear (CS) cytology and cell block preparation in serous effusions.
\end{abstract}

\section{MATERIALS AND METHODS}

In this Descriptive study, material for both conventional cytology and cell blocks were collected simultaneously as per convenience. Total 98 samples were evaluated. Grading of cellularity, morphological preservation, architectural preservation and presence of background staining were compared.

\section{RESULTS}

Of the total 98 undergoing conventional cytological analyses, 74 (75.5 \%) were reported as benign, 19 (19.3\%) as malignant and 05 $(5.10 \%)$ as suspicious of malignancy. With the cell block method, the results were $76(77.55 \%)$ benign and $22(22.44 \%)$ malignant.

\section{CONCLUSION}

Our study confirmed that the cell block method increases the diagnostic yield. Direct fluid smears and cell blocks complement each other, and our results indicate that both are needed in the diagnostic work-up of patients.

\section{KEYWORDS}

Cellblock Technique; Cell Block.

HOW TO CITE THIS ARTICLE: Singh R, Hayer SS, Mane VP, et al. A comparative study of cell block with conventional smear cytology in diagnosing serous effusions- a descriptive study. J. Evolution Med. Dent. Sci. 2018;7(06):771-773, D0I: $10.14260 /$ jemds/2018/175

\section{BACKGROUND}

Conventional cytology plays a major role in diagnosis of various fluids. But examination of the remaining residue which is not processed during conventional method is very helpful. Conventional cytology and cell block study together plays an important role in the diagnosis of lesions. Hence, the present study is undertaken. It has been widely accepted that this method of analysis increases the cellular yield and improves diagnostic accuracy.[1,2]

The ability to obtain numerous sections allows for multiple immunostains and other studies to be performed akin to paraffin sections produced in histopathology.[3] The cytological examination of serous fluids is important in the

'Financial or Other Competing Interest': None.

Submission 31-07-2017, Peer Review 22-01-2018,

Acceptance 29-01-2018, Published 05-02-2018.

Corresponding Author:

Dr. Ravi Singh,

Flat No.1 Shri Ramshailya Apartment,

Neminath Nagar, Sangli.

E-mail: vaishnavilab1060@gmail.com

DOI: $10.14260 /$ jemds $/ 2018 / 175$

(c) (i) $(9)$ diagnosis, staging and the prognosis of malignant lesions. The cytodiagnosis which is made by conventional smears has got a lower sensitivity due to the overcrowding of the cells, cell loss and also due to the different laboratory processing methods.

The accurate identification of the malignant or reactive mesothelial cells is a diagnostic problem in conventional cytological smears.[1] The cell block method is also used previously.[2] The routine use of $\mathrm{CB}$ by agar or plasma thrombin is not cost effective, as it needs additional material. A new method of the CB preparation which uses $10 \%$ alcoholformalin as a fixative which is being used is a simple, inexpensive method, and it does not require any special training or instrument. This method increases the cellularity, gives better morphological details and it also improves the sensitivity of the diagnosis.[1] Therefore, the CB technique can be considered as a useful adjuvant in evaluating the fluid cytology for a final cytodiagnosis along with the routine CS method.

\section{Aims and Objectives}

The present study is undertaken to assess diagnostic efficacy of cell block preparation (CB) by combined approach of 
conventional smear (CS) cytology and cell block preparation in serous effusions.

\section{MATERIALS AND METHODS}

This study was a descriptive study. Fluids were collected for cytological evaluation in the Cytology Section. It is evaluated by conventional and cell block method as follows.

\section{The Conventional Smear Technique}

The sample (app. 5 - $10 \mathrm{~mL}$ ) was centrifuged and smears were prepared from the sediment. One air dried stained with Giemsa stain. Other fixed in Pap fixative stained by $\mathrm{H}$ and $\mathrm{E}$ stain.

\section{The Cellblock Technique}

The sample was fixed by adding with equal amount of alcohol formalin and then centrifuged at $2500 \mathrm{rpm}$ for $1 \mathrm{hr}$. A further $3 \mathrm{~mL}$ of fresh $10 \%$ alcohol-formalin was once again added to the sediment after discarding the supernatant and it was kept for 24 hours. On the next day, the sediment which contained the cell button was scooped out onto a filter paper. This cell button was processed along with other routine biopsy specimens. After paraffin embedding $4-6 \mu$ thickness sections were prepared from this cell button (Cell block) and they were stained with the haematoxylin and eosin stain.

\section{The Interpretation of $\mathrm{CS}$ versus $\mathrm{CB}$}

The clinical details were obtained from patient record files. The samples were reported as benign, suspicious for malignancy and malignant lesions depending upon the cytological criteria. A comparative evaluation of the CS versus the $\mathrm{CB}$ techniques was conducted.

\section{RESULTS}

98 fluid samples were subjected to the CS and the CB techniques. The ages of the patients ranged from 21 to 80 years. The female patient's samples outnumbered the male patient's samples. The cellular yield which was obtained by the CB method was more when it was compared to that which was obtained by the CS method.

Architectural patterns such as glands, three-dimensional cell clusters, cell balls and sheets were commonly observed in the $\mathrm{CB}$ method as compared to the singly scattered cells, glands and cell clusters which were found in the CS findings. The results were reported as benign, suspicious of malignancy and malignant. By cell block method we reported 3 more cases of malignancy, which were reported as suspicious of malignancy on conventional methods. The female-to-male ratio was 2: 1 for the malignant effusions.

The most common primary malignancy identified was from the ovary. Therefore, in this study, the utility of the $\mathrm{CB}$ method in the cytodiagnosis of malignant effusions was found to be highly significant as compared to the CS method.

\begin{tabular}{|c|c|c|c|c|}
\hline $\begin{array}{c}\text { Cytological } \\
\text { Category }\end{array}$ & $\begin{array}{c}\text { Conventional } \\
\text { Smears No. }\end{array}$ & $\begin{array}{c}\text { Conventional } \\
\text { Smears \% }\end{array}$ & $\begin{array}{c}\text { Cell } \\
\text { Block }\end{array}$ & $\begin{array}{c}\text { Cell Block } \\
\text { Smears \% }\end{array}$ \\
\hline $\begin{array}{c}\text { Benign } \\
\text { (Inflammatory) }\end{array}$ & 74 & 75.5 & 76 & 77.55 \\
\hline Suspicious & 05 & 5.10 & 00 & 00 \\
\hline Malignant & 19 & 19.3 & 22 & 22.44 \\
\hline Total & $\mathbf{9 8}$ & $\mathbf{1 0 0}$ & $\mathbf{9 8}$ & $\mathbf{1 0 0}$ \\
\hline \multicolumn{4}{|r|}{ Table 1. Distribution of Cytological Category } \\
\hline
\end{tabular}

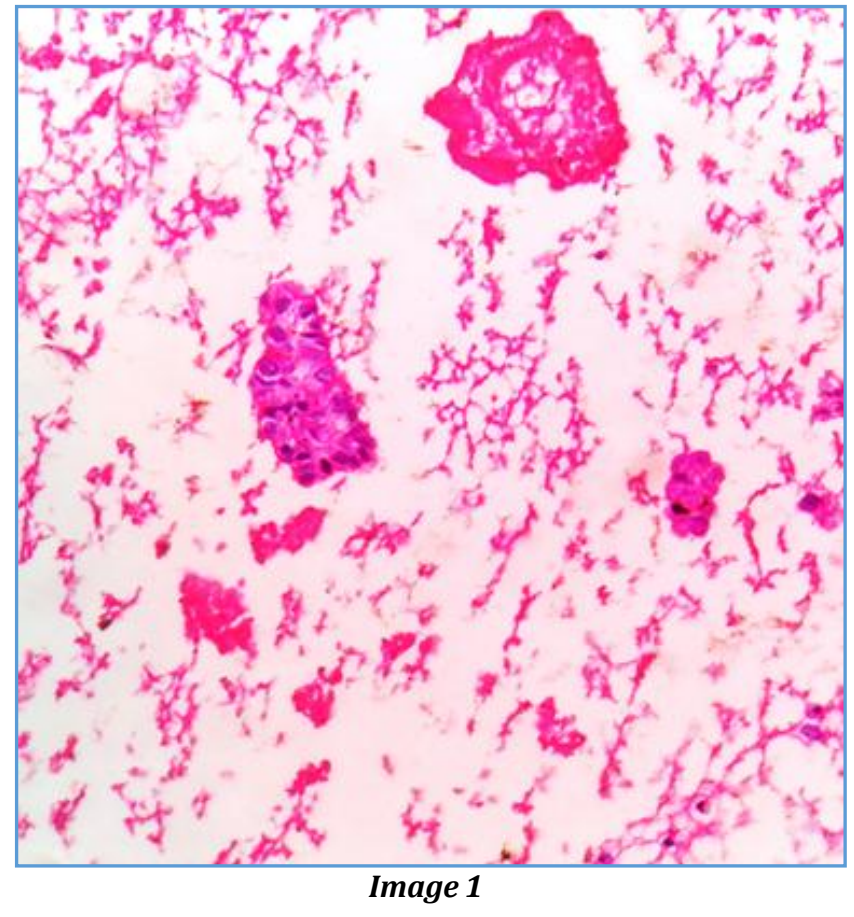

Image 1. Cell block preparation. Pleural Fluid. (H and E 40x): Positive for malignancy. On conventional cytology reported as suspicious of malignancy.

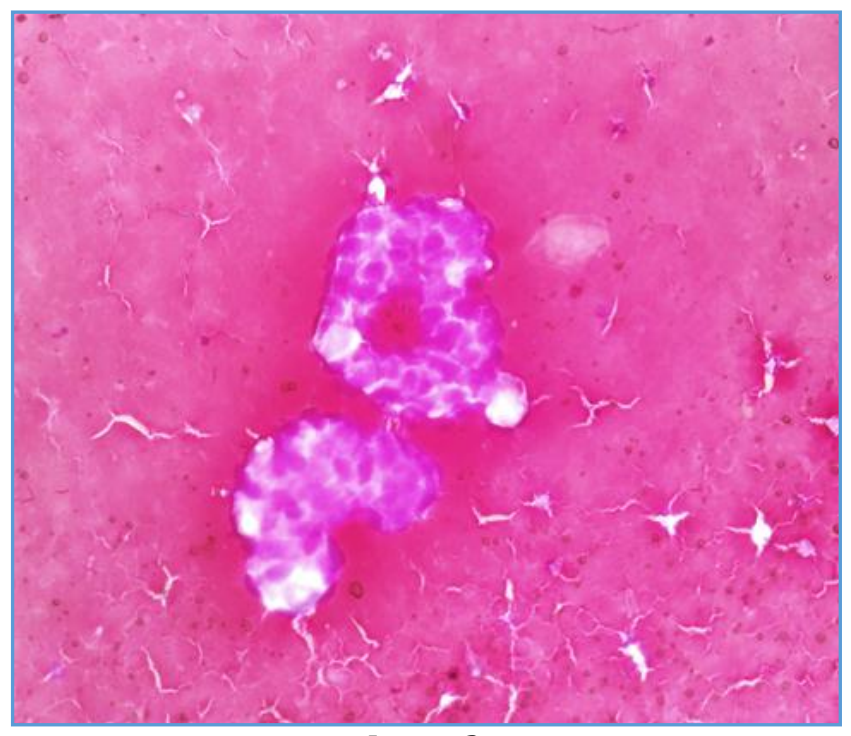

Image 2

Image 2. Cell Block Ascitic Fluid: Positive for Malignancy (H and E, 40x) Conventional Cytology: Suspicious for malignancy.

\section{DISCUSSION}

The cytological examination of serous effusions is of paramount importance in diagnostic, therapeutic and prognostic implications. It plays a major role to know the primary site of malignancy and sometimes in staging of these lesions. ${ }^{[4]}$

Hence, presently, the examination of body fluids for the presence of malignant cells has been accepted as a routine laboratory procedure, not only for the detection of unsuspected cancers but also for the detection of metastasis of an unknown primary origin. $[1,3,5]$ 
Beale introduced the paraffin-block method for serous effusions in 1895.[6] In 1896, Bahrenberg first described the cellblock technique and it was commonly used after Mandlebaum reported the finding of actinomyces in a cell block.[7]

In the CS method, reactive mesothelial cells, an abundance of inflammatory cells and a paucity of representative cells contribute to the considerable difficulties which are faced in making conclusive diagnosis.

The reactive mesothelial cells may show reactive changes such as cytomegaly, nucleomegaly, multinucleation, mitotic figures and a high $\mathrm{N} / \mathrm{C}$ ratio.

As the sensitivity of conventional cytology ( $40 \%-70 \%)$ is less as compared to cell block preparation, there are some limitations in diagnosis of malignant lesions.[8]

Sometimes the cytomorphological features are not very diagnostic, because of overcrowding of cells or cytological atypia due to various processing methods.[9]

For this reason, in this study an attempt was made to prepare and to analyse both the CS and the CB which were prepared by using $10 \%$ alcohol-formalin as a fixative from the same specimen.

Conventional cytology is a routinely practiced procedure. It is simple, cost effective as compared to cell block preparation. But in cell block preparation, the architectural pattern is better appreciated than in conventional cytology.[10]

The CBs which are prepared from the residual tissue and fluids can be particularly useful for the identification of the tumours that cause diagnostic difficulties on smears. This technique is simple, reproducible and safe.

Further, the effectiveness of the cell block lies in the availability of the diagnostic material for further histological examination, histochemistry and IHC studies for a better classification of the tumour and for the identification of infectious causes by using microbiologic stains. $[3,6,9,10]$

The main advantages of the CB procedure include recognition of the histological patterns of diseases. The disadvantage with the cellblock technique is a delay in the diagnosis when it is compared to the conventional smears and sometimes the risk of losing material during the processing.[10] Some mesothelial cells because of centrifugation artefacts may form rosettes or pseudoacini which can be the sources of a misdiagnosis.[8,9]

The CB technique which uses $10 \%$ alcohol-formalin as a fixative was found to be simple and inexpensive and it did not require special training or special instruments. By using formalin the proteins would become cross linked and a gel would be formed which could not be dissolved in any material during sample processing, thus minimising the cell loss.[3] To achieve the maximum usefulness of $\mathrm{CB}$, the fixation and the processing of the samples had to be modified.

By using $5 \%-10 \%$ formalin, results which were comparable to those of the biopsy reports were obtained.[6,7] The use of an alcohol based fixative provides a better preservation of the antigenicity and also cytomorphological features which are comparable to those of the conventional smears.[10]

\section{CONCLUSION}

To conclude, the present study results showed that the $\mathrm{CB}$ technique which used $10 \%$ alcohol-formalin as a fixative was a simple, safe, reproducible and inexpensive method which did not require any special training or instrument. Cell block preparation shows increased cellularity and better cellular details. Hence, the CB technique can be recommended as a useful adjuvant in evaluating the fluid cytology for a final cytodiagnosis along with the routine CS method.

The CB method provides high cellularity, better architectural patterns, morphological details and an additional yield for malignant cells. Therefore, cell block study should be done routinely along with conventional methods for better diagnosis.

\section{Limitations}

Since it is a descriptive and a small sample size study, it may not be reflecting the community well. This is the limitation of the study. However, it should be stated that all lesions need histopathological examination for proper diagnosis and prognosis.

\section{REFERENCES}

[1] Dekker A, Bupp PA. Cytology of serous effusions. An investigation into the usefulness of cell blocks versus smears. Am J Clin Pathol 1978;70(6):855-60.

[2] Thapar M, Mishra RK, Sharma A, et al. Critical analysis of cell block versus smear examination in effusions. J Cytol 2009;26(2):60-4.

[3] Bista P. Comparison of the diagnostic accuracy of cell block with cytology smear in serous effusions. Journal of Pathology of Nepal 2013;3(6):482-6.

[4] Shivakumarswamy U, Arakeri SU, Karigowdar MH, et al. Diagnostic utility of the cell block method versus the conventional smear study in pleural fluid cytology. J Cytol 2012;29(1):11-5.

[5] Udasimath S, Arkeri SU, Karigowdar MH, et al. The role of cellblock method in the diagnosis of malignant ascitic fluid effusions. Journal of Clinical and Diagnostic Research 2012;6(7):1280-3.

[6] Bhanvadia VM, Santwani PM, Vachhani JH. Analysis of diagnostic value of cytological smear method versus cell block method in body fluid cytology: study of 150 cases. Ethiop J Health Sci 2014;24(2):125-31.

[7] Grandhi B, Shanthi V, Rao NM, et al. Diagnostic utility of cell block as an adjunct to cytological smears. Int J Med Res Health Sci 2014:3(2):278-84.

[8] Sujathan K, Pillai KR, Chandralekha B, et al. Cytodiagnosis of serous effusion: a combined approach to morphological features in Papanicolaou and May-Grunwald Giemsa stained smears and modified cellblock technique. J Cytol 2000;17(2):8995.

[9] Mayall F, Chang B, Darlington A. A review of 50 consecutive cytology cell block preparations in a large general hospital. J Clin Pathol 1997;50(12):985-90.

[10] Kushwaha R, Shashikala P, Hiremath S, et al. Cells in pleural fluid and their value in differential diagnosis. J Cytol 2008;25(4):138-43. 